\title{
The relationship between water buffalo cow temperament and milk yield and quality traits
}

\author{
Monique Valéria de Lima Carvalhal ${ }^{\mathrm{a}, \mathrm{b}}$, Aline Cristina Sant’Anna ${ }^{\mathrm{b}, \mathrm{c}}$, Adriano Gomes Páscoa ${ }^{\mathrm{d}}$, \\ Jens Jung ${ }^{\mathrm{e}}$, Mateus José Rodrigues Paranhos da Costa ${ }^{\mathrm{b}, \mathrm{f}, *}$ \\ a Programa de Pós-Graduação em Zootecnia, Faculdade de Ciências Agrárias e Veterinárias, UNESP, 14.884-900, Jaboticabal, SP, Brazil \\ b Grupo de Estudos e Pesquisas em Etologia e Ecologia Animal, Departamento de Zootecnia, Faculdade de Ciências Agrárias e Veterinárias, UNESP, 14884- \\ 900, Jaboticabal, SP, Brazil \\ ${ }^{\mathrm{c}}$ Departamento de Zoologia, ICB, UFJF, 36036-900, Juiz de Fora, MG, Brazil \\ a BEA Consultoria e Treinamento, 38190-000, Sacramento, MG, Brazil \\ e Department of Animal Environment and Health, Swedish University of Agricultural Sciences, 532 23, Skara, Sweden \\ ${ }^{\mathrm{f}} \mathrm{CNPq}$, Brazil
}

\section{A R T I C L E I N F O}

\section{Keywords}

Animal behavior

Bubalus bubalis

Daily distance traveled

Milk production

Reactivity

Somatic cell count

\begin{abstract}
A B S T R A C T
The aims of this study were to assess the relationship between reactivity during milking and daily distances traveled by lactating water buffalo cows and to assess the association of these behavioral traits with milk yield and quality traits. Reactivity during milking was measured as a 4-point milking reactivity score (MRS, N=114 cows) where 1 =stands quietly, $2=$ =slight hind leg movements, $3=$ =vigorous hind leg movements, and 4=continual vigorous hind leg movements or the stockperson ties the animal. Cows were classified according to their consistency for MRS within each month as 1) inconsistent (same MRS in fewer than 50\% of observations), 2) moderately consistent (same MRS in 50-74.9\% of observations), or 3) consistent (same MRS in at least $75 \%$ of observations). GPS collars were used to calculate the average daily distance traveled (DDT) by each cow ( $N=36)$. Milk yield and quality traits (fat, protein and lactose content, as well as somatic cell count) were measured once a month during the three months of the study. Results showed that DDT was not related to MRS ( $F=0.78$, $\mathrm{P}=0.47)$. Furthermore, MRS was negatively associated with milk yield $\left(\mathrm{F}_{2,66}=3.75 ; \mathrm{P}=0.02\right)$, fat content $\left(\mathrm{F}_{2,71}=3.34 ; \mathrm{P}=0.04\right)$, and linear somatic cell score (LSCS) $\left(\mathrm{F}_{2,69}=4.06 ; \mathrm{P}=0.02\right)$. Reactive cows $(\mathrm{MRS} 3+4)$ had lower daily milk yield than MRS 1 cows, with lower fat content and higher LSCL than MRS 2 cows. On the other hand, DDT was not associated with milk yield or any quality traits $(\mathrm{P}>0.05)$ other than $\operatorname{LSCS}\left(\mathrm{R}^{2}=0.60 ; \mathrm{P}<\right.$ 0.05). Since MRS and DDT were not correlated, we conclude that these traits reflect distinct aspects of water buffalo cows' temperament. Milk yield and quality were not related to DDT, indicating that only MRS was associated with the productive traits in lactating water buffalo cows.
\end{abstract}

\section{Introduction}

As the animal with the greatest milk production in several countries, domestic water buffaloes (Bubalus bubalis) significantly contribute to the world's milk production (Borghese and Mazzi, 2005). Therefore, it is important to understand how handling routines can influence the welfare and productivity of these animals. A useful way to address this issue is to study individual cows' behavioral and physiological responses to handling, as well as how these responses are associated with milk yield and quality traits (Prasad et al., 2011).

These variations are known as animal temperament, which is defined by the expression of individual behavioral differences that are consistent over time and/or situations (Réale et al., 2007). Animal temperament involves the expression of several behaviors, which makes its measurement difficult. To overcome this challenge, researchers use the operational definition of temperament, which takes into account animals' behavioral responses to handling by humans (Burrow, 1997). Temperament is frequently assessed by visual scores that consider the frequency and intensity of movements and other behaviors reflecting levels of animal fear and reactivity (Breuer et al., 2000; Wenzel et al., 2003; Rousing et al., 2004; Hedlund and Løvlie, 2015).

Some authors have reported an association between dairy cows' reactivity during milking and their degree of susceptibility to stress, which in turn affects milk yield and quality traits (Rousing et al., 2004;

\footnotetext{
* Corresponding author at: Grupo de Estudos e Pesquisas em Etologia e Ecologia Animal, Departamento de Zootecnia, Faculdade de Ciências Agrárias e Veterinárias, UNESP, 14884900, Jaboticabal, SP, Brazil.

E-mail address: mpcosta@fcav.unesp.br (M.J.R. Paranhos da Costa).
} 
Bertenshaw et al., 2008; Hedlund and Løvlie, 2015). By contrast, other authors have failed to find a significant relationship between cow behaviors (i.e. flight distance and step and kick responses during milking) and milk yield (Purcell et al., 1988; Uetake et al., 2002; Waiblinger et al., 2002). Yet another set of studies found effects of reactivity on milk yield only for specific behavioral indicators of reactivity, making it even more difficult to construct a general understanding of this phenomenon (Dodzi and Muchenje, 2011; Hedlund and Løvlie, 2015). Although lactating water buffalo cows are known to be more sensitive to handling during milking than dairy cows, few studies have addressed their reactivity to handling, and have focused mostly on cows' stress physiology and milk letdown (Pathak, 1992; Thomas et al., 2005; Bidarimath and Aggarwal, 2007).

In order to get a broader view of cows' individuality, other aspects of temperament should also be considered, such as cows' overall activity levels, which are considered an important aspect of animal temperament (Réale et al., 2007). One study reported that long-term activity levels are linked to short-term reactivity in cattle (Mackay et al., 2013), thus characterizing one aspect of their individuality (Wesley et al., 2012). Moreover, in dairy cattle, some have suggested that daily activity levels can affect milk production (Bewley et al., 2010; Norring et al., 2012), as well as animal behavior (Telezhenko et al., 2012) and health (Gustafson, 1993; Davidson and Beede, 2003).

It is currently unknown to what extent water buffaloes' short-term reactivity is associated with their long-term activity levels. However, a reasonable hypothesis is that animals that are more reactive during milking should also be more active in the pastures, reflecting a temperament dimension that is associated with overall activity. In order to test these ideas, the aims of the current study were: 1) to assess the relationship between water buffalo cows' reactivity during milking and the daily distance traveled (taken as an indicator of general activity); and 2) to evaluate the association of these temperament traits with milk yield and quality traits (protein and fat contents, and somatic cell count).

\section{Materials and methods}

This study was approved by the commission for the ethical use of animals of FCAV - UNESP (Jaboticabal-SP, Brazil), protocol number $011587 / 13$. Data collection was conducted on a private farm that produces organic milk for mozzarella cheese, located in the municipality of Brodowski, São Paulo State, Brazil.

A total of 114 lactating water buffalo cows (Murrah purebred and Murrah $\times$ Jaffarabadi crossbred, 99 multiparous and 15 primiparous) were evaluated from March to May 2013. The animals were kept in a single social group. The cows averaged $93.25 \pm 59.77$ (mean \pm standard deviation) days in lactation and had experienced $3.67 \pm 1.92$ calvings. They were milked twice a day (at 05:00 A.M. and 02:00 P.M.) in a tandem milking parlor, with calves tied close to their mothers, but without access to the udder during milking. Natural suckling was used just before the pre-dipping procedure to stimulate milk let-down. After suckling for less than one minute, the calves were tied in the milking parlor structure close to the cows' head. Milking was always carried out by the same two stockpersons. After each milking session, the calves stayed with their mothers for approximately one hour, with access to the udder to suckle the residual milk.

Between the morning and afternoon milkings, the animals were kept indoors with free access to drinking water and fed ad libitum with a total mixed ration composed of corn silage, chopped sugarcane, wet brewer's spent grain and mineral supplements. After the afternoon milking, the cows were moved to the indoor cow sheds, where they had free access to one of two paddocks.

Before assessing milking reactivity, preliminary observations were conducted over seven days to habituate the cows to the observer's presence. The reactivity assessments were performed in the milking parlor by only one trained observer. Direct observations with focal sampling and continuous recording (Martin and Bateson, 1993) were performed at the time of fitting the teat cups, and the milking reactivity scores (MRS) based on leg movement were assigned as follows: $1=$ cow stands quietly; $2=$ cow shows some slight movements with one or both hind legs; $3=$ cow shows vigorous movements with one or both hind legs; and 4= cow shows continual vigorous hind leg movements, or the stockperson ties the hind legs (adapted from Paranhos da Costa and Broom (2001)).

The MRS was assigned during both the morning and afternoon milking sessions, yielding at least 14 measurements per month for each cow. Cows were classified according to the consistency of their MRS within each month, following the criterion used by Paranhos da Costa and Broom (2001), which defines three groups: inconsistent $(\mathrm{N}=36)$, for cows that received the same MRS score in fewer than $50 \%$ of the observations within each month; moderately consistent $(\mathrm{N}=38)$, for those that received the same MRS score in $50-74.9 \%$ of the monthly observations; and consistent $(\mathrm{N}=40)$, for cows that received the same MRS score in more than $75 \%$ of the monthly observations. For cows classified as consistent, the MRS classification for each cow was used to define a single MRS per cow per month.

The distances traveled per day were assessed in 36 water buffalo cows (randomly assigned from the 114 studied cows) over a period of 10 weeks. GPS collars (GPS Plus-2 Vectronic Aerospace GmbH, Berlin) were used to record the distance traveled, which was used as an indicator of individual activity levels. The collars were fitted randomly to groups of three to five cows each time, and each group of cows remained with the collar for four whole days and nights, totaling $96 \mathrm{~h}$ of individual monitoring. During this period, cows alternated between two paddocks, as follows: paddock 1 ( $49.5 \mathrm{ha}$ ) - from weeks $1-5$ and week 10, and paddock 2 (27.7 ha) - from weeks 6-9. Both paddocks had a complex vegetation cover, with forest fragments combining different species of trees and bushes, as well as some areas of rock outcrop. The predominant grass species in both paddocks were Panicum maximum Jacq cv Colonião and Cynodon nlemfuensis. A paddock effect was included in the statistical analyses of the average daily distance traveled for correction purposes.

Each collar was configured to record animal location (UTM Universal Transversor Mercator) at 30-s intervals. For each record (location point), the following variables were logged: collar number, date, time, latitude, longitude, altitude and the dilution of precision (DOP, a measure of the predictive accuracy of the obtained location; smaller DOP values indicate more accurate location measurements).

The GPS Plus (VECTRONIC Aerospace) and Microsoft Excel programs were used to calculate the distances traveled by each cow every $30 \mathrm{~s}$, using Pythagoras' theorem in the following equation: Distance traveled $=\left(\left(\mathrm{T}_{2} \text { Latitude-Latitude } \mathrm{T}_{1}\right)^{2}+\left(\mathrm{T}_{2}\right.\right.$ Longitude-Longitude $\left.\left.\mathrm{T}_{1}\right)^{2}\right)^{0.5}$, where: Latitude $\mathrm{T}_{1}$ : is the first latitude point recorded by the GPS collar; Latitude $\mathrm{T}_{2}$ : is the second latitude point recorded by the GPS collar after $30 \mathrm{~s}$; Longitude $\mathrm{T}_{1}$ : is the first longitude point recorded by the GPS collar; Longitude $\mathrm{T}_{2}$ : is the second longitude point recorded by the GPS collar after $30 \mathrm{~s}$. Subsequently, the values were summed to obtain the distance traveled per cow per day (m). The distances traveled per cow per day were used to estimate the means and then the average of the four days was calculated (DDT).

The daily milk yield per water buffalo cow (kg/day) was measured once a month during the three months of data collection. Simultaneously, individual samples were collected from each animal to evaluate milk quality traits. Samples were sent to the Clínica do Leite Laboratory, located in the Department of Animal Science of the Escola Superior de Agricultura "Luiz de Queiroz", at the University of São Paulo, Piracicaba, São Paulo State, Brazil. The following milk quality traits were assessed: fat (\%, mass solute/mass total solution), protein $(\%, \mathrm{~m} / \mathrm{m})$ lactose $(\%, \mathrm{~m} / \mathrm{m})$ and total solids contents $(\%, \mathrm{~m} / \mathrm{m})$, and the somatic cell count $(\mathrm{SCC}, \times 1000$ cells $/ \mathrm{mL}$ ). Infrared spectroscopy was used to determine fat, protein and lactose contents, and SCC was assessed by flow cytometry. 


\subsection{Statistical analysis}

The statistical analyses were performed using the SAS software (version 9.0, SAS Institute Inc., Cary, NC, USA). The Shapiro-Wilk test was used to verify the normality of the data for all the dependent variables. The SCC variable was not normally-distributed; thus, a logarithmic transformation was applied to yield a linear somatic cell score (LSCS), given by the following equation: LSCS=[log (SCC/ 100,000)]+3 (Ali and Shook, 1980).

A chi-square test of independence was used to test whether the frequency of MRS consistency classes varied across the three months of the study. Spearman's rank correlation coefficients were estimated to assess whether the ranking of water buffalo cows for distance traveled remained constant throughout the evaluations.

To assess the relationship between MRS and DDT, a general linear model was fitted, using the GLM procedure in SAS. The model included DDT as the response variable and the fixed effects of MRS $(1,2,3+4$ '), stage of lactation (in 10 classes, defined according to month of lactation), parity (from 1 to $\geq 10$ calvings), month of assessment (March, April or May) and paddock (1 or 2). The means comparison was performed using the Tukey-Kramer test. For this subset of data, a score of 4 occurred infrequently (around $5 \%$ of animals over the three months assessed). Those animals were then grouped with those with a score of 3 to form reactivity class ' $3+4$ '.

A linear mixed model was fitted to assess the relationship between MRS and milk yield and quality (fat, protein, lactose, total solids, and LSCS), using the MIXED procedure in SAS. The models included MRS $(1,2$ or ' $3+4$ '), stage of lactation (in 10 classes, defined according to month of lactation), parity (from 1 to $\geq 10$ calvings) and month (March, April or May) as fixed effects, as well as the random effect of animal repeated within month. Means were compared using a post-hoc Tukey test. The duration of lactation was categorized by dividing the number of days in lactation by 30 , which yielded 10 lactation period categories. These analyses were conducted using information from consistent cows only.

Next, a linear model was fitted to assess the relationship between the distance traveled and milk yield and quality. For this, we used the PROC GLM in SAS, considering the fixed effects of MRS (1, 2, '3+4'), stage of lactation (in 10 classes, defined according to month of lactation), parity (from 1 to $\geq 10$ calvings), month (March, April or May) and paddock ( 1 or 2 ), plus DDT as a covariate with linear effects.

\section{Results}

\subsection{Characterization of the reactivity and general activity of water buffalo cows}

The distribution of the reactivity consistency classes differed across months $\left(\chi^{2}=22.29\right.$; $\left.d f=4 ; P<0.01\right)$. The percentage of animals classified as inconsistent for MRS decreased across months, with 26.97, 13.48 and 3.06\% in March, April and May, respectively. By contrast, there was an increase in the moderately consistent (42.70\% in March, 53.93\% in April and 57.14\% in May) and consistent classes (30.34, 32.58 and $39.80 \%$, for March, April and May, respectively). There was a reduction in the number of animals with a score of 1 for MRS, and an increase in the number of animals with a score of 2 over the months, as shown in Fig. 1a (all individuals) and b (only consistent cows). The percentage of animals with a score of 4 remained relatively stable and infrequent, suggesting that this condition may be difficult to reverse.

The average daily distance traveled by water buffalo cows $(\mathrm{N}=36)$ was $7,413 \pm 1,039 \mathrm{~m} /$ day (mean \pm standard deviation), ranging from 5,762 to $10,124 \mathrm{~m} /$ day. According to Spearman's rank correlation coefficients, daily distances traveled showed inter-individual variation and moderate to high consistency throughout the study period, ranging from 0.38 to 0.78 (Table 1 ). There was no significant relationship between DDT and MRS $\left(\mathrm{F}_{2,35}=0.78 ; \mathrm{P}=0.47\right)$.
3.2. Association of reactivity and general activity with milk yield and quality traits

For consistent animals, there was a significant relationship of MRS with milk yield $\left(\mathrm{F}_{2,66}=3.75 ; \mathrm{P}=0.02\right)$, $\mathrm{LSCS}\left(\mathrm{F}_{2,69}=4.06 ; \mathrm{P}=0.02\right)$ and fat content $\left(\mathrm{F}_{2,71}=3.34, \mathrm{P}=0.04\right)$, but not with protein $\left(\mathrm{F}_{2,71}=0.04\right.$, $\mathrm{P}=0.95)$, lactose $\left(\mathrm{F}_{2,71}=0.96, \quad \mathrm{P}=0.38\right)$ or total solids contents $\left(\mathrm{F}_{2,71}=2.74, \mathrm{P}=0.07\right)$. Cows with MRS 1 had a higher average daily milk yield than those with MRS 2 and MRS 3+4, and these last two groups did not differ from each other (Table 2). The milk of the most reactive cows (MRS 3+4) had lower fat content than that of the MRS 2 cows, and also tended $(\mathrm{P}=0.08)$ to be lower than that of the MRS 1 cows. Furthermore, cows with MRS $3+4$ also exhibited significantly higher LSCS than those with MRS 2, but did not differ from MRS 1 cows in this respect $(\mathrm{P}=0.14)$.

No significant relationships between DDT and milk yield, fat and protein content $(\mathrm{P}>0.05)$ were observed, and there was only a significant linear regression between DDT and LSCS. Although this last association was significant, the magnitude of change in LSCS due to an increase in DDT was low, as characterized by the following equation: $\mathrm{LSCS}=4.13+0.00014 * \mathrm{DDT}\left(R^{2}=0.60 ; \mathrm{P}<0.05\right)$.

\section{Discussion}

The reactivity of water buffalo cows in the milking parlor was assessed over the study's three-month duration. The higher percentage of animals classified as 'consistent' indicates that animals' behavioral response to teat cup fittings became more stable over time as well as more uniform across members of the whole group. This is reflected in the greater number of MRS 2 cows (defined by mild movements of one or both hind legs when fitting the teat cups), which may in turn reflect animals' habituation to stimuli present during milking, even after an average of three months of milking. Similarly, Porcionato et al. (2009) observed a decrease in the number of dairy cows presenting 'undesirable' behaviors during milking after the fourth week of lactation, which, according to the authors, may have occurred due to animals' habituation to handling. In their 2015 article, Hedlund and Løvlie reported that dairy cows had higher consistency for stepping behavior during milking than for other behavioral measures, which highlights the importance of assessing the consistency of individual temperament measures over time. Most cows assessed in the present study were at least moderately consistent in their expression of milking reactivity, which indicates that the MRS is a useful tool for assessing water buffalo cow temperament. An alternative explanation for the high incidence of MRS 2 cows might be that a scale with only 4 points, as is the case of the MRS, may not be sensitive enough to assess reactivity. Perhaps this scale does not adequately reflect the range of behavioral variation, especially in the calmer animals with scores of 1 or 2 .

The average daily distance traveled by the water buffalo cows showed inter-individual variation and moderate to high consistency over the days assessed, thus we assumed that DDT may reflect individual cows' activity levels, which would in turn indicate temperament (Réale et al., 2007). The DDT in the present study was longer than the average distance observed by Sabia et al. (2014) for water buffalo heifers kept on a Mediterranean natural pasture $(2.1 \pm 0.3 \mathrm{~km}$ per day). To date, no studies on water buffalo or dairy cows have assessed animal activity in their home range as an indicator of temperament. This behavioral trait has been studied in beef cattle, where DDT has been associated with climatic variables (Anderson and Kothmann, 1980), type of grazing systems (Hepworth et al., 1991), nutritional quality of available forage (Ganskopp and Bohnert, 2006) and spatial distribution of biotic and abiotic factors affecting grazing (Ganskopp, 2001). In a detailed study by Wesley et al. (2012), the authors considered average daily distance traveled, tortuosity of the trajectory, time spent close to the water drinker and feeding behavior and classified heifers into two different behavioral groups. Their results 
(a)

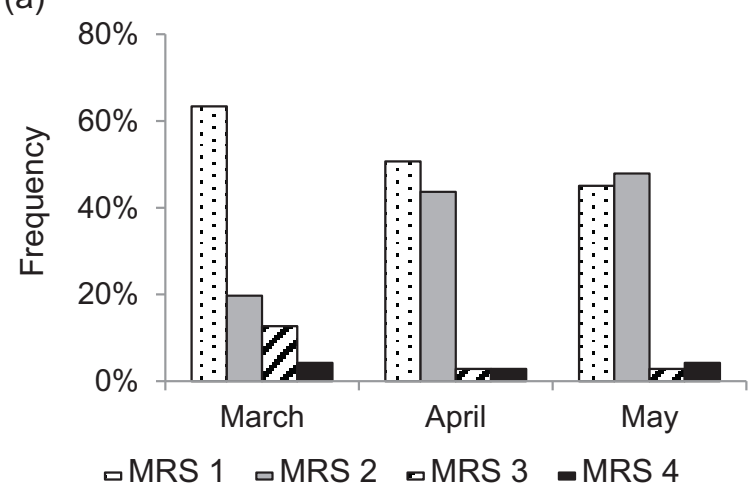

(b)

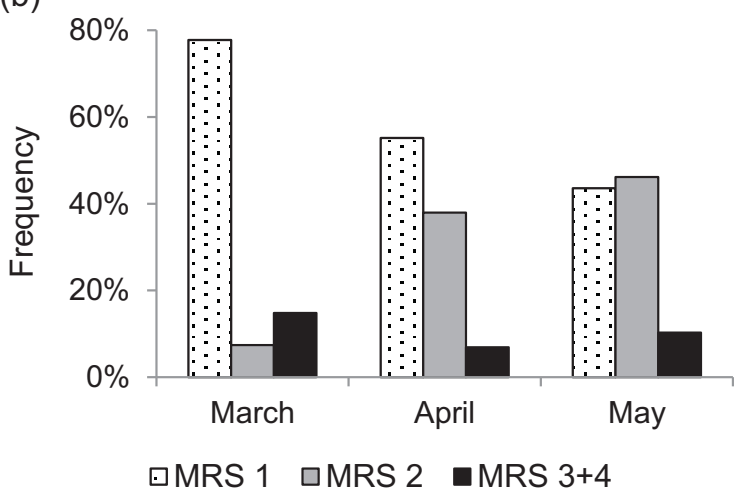

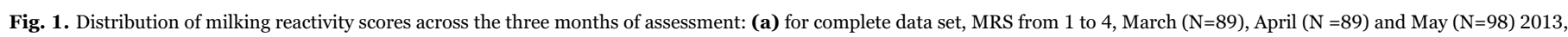
and (b) for the subset of consistent animals, MRS from 1 to 3+4, March (N=27), April (N=29) and May (N=39), 2013.

Table 1

Spearman's rank correlation coefficients between the daily distances traveled according to the assessment days (above diagonal) and number of animals observed (below diagonal).

\begin{tabular}{lllll}
\hline & Day 1 & Day 2 & Day 3 & Day 4 \\
\hline Day 1 & - & $0.38^{* *}$ & $0.46^{* * *}$ & $0.49^{* * * *}$ \\
Day 2 & 36 & - & $0.78^{* * *}$ & $0.45^{* * *}$ \\
Day 3 & 36 & 36 & - & $0.42^{* * *}$ \\
Day 4 & 35 & 35 & 35 & - \\
\hline
\end{tabular}

Spearman's rank correlation coefficients.

* P-value $<0.05$.

** P-value $<0.001$.

showed that the behavioral variables defining the two groups may be used to assess some aspects of heifers temperament, which they called 'behavioral syndrome'.

The lack of a significant relationship between DDT and MRS contradicts our hypothesis, which was that an animal that is more reactive during milking will walk more in the pasture as a result of their higher overall activity level. In the present study, milking reactivity can be characterized as a response to environmental stimuli present in the milking parlor, which is mainly due to proximity to humans. On the other hand, the level of locomotion activities depends on other environmental stimuli, including motivation to express exploratory behavior, and may also be related to the individual cow's foraging strategies. Therefore, we conclude that these indicators (MRS and DDT) address different aspects of water buffalo cow temperament. To date, no study has addressed the association between milking reactivity and the distance traveled by water buffalo cows. For beef cattle, MacKay et al. (2013) assessed the association between the activity of steers in feedlot pens (measured using pedometers, which generated a motion index) and their temperament during handling in the corral by applying a 6-point reactivity score when the steers were within the cattle crush and a flight speed test. Similarly to us, the authors did not find a significant association between the motion index and the reactivity score. According to those authors, the reactivity score is a useful tool to assess the reaction of animals to humans and handling, but it is not efficient to evaluate broader aspects of cattle temperament.

Regarding the negative associations of reactivity with milk yield, fat content and LSCS, our outcomes support the findings of Prasad and Laxmi (2014), who observed that water buffalo cows classified as 'docile' had significantly greater milk production than those classified as 'nervous'. The same trend was found for dairy cattle: cows that stepped more during milking produced less milk on their first lactation (Hedlund and Løvlie, 2015). However, the authors concluded that the relationship between the cows' behavioral responses and milk production is more complex, and that it depends on the productive and behavioral measures used and the breed investigated. According to Murray et al. (2009), the differences found in sheep milk yield and quality as a function of temperament could be explained by differences in animals' susceptibility to stress.

It has also been shown that more reactive cattle have more intense stress responses relative to calmer ones (Café et al., 2011). Under acute stress, the release of catecholamines inhibits the action of oxytocin, which leads to increased residual milk and a consequent reduction in milk yield. Similarly, under chronic stress, an increase in glucocorticoid concentrations leads to changes in energy metabolism, which may also impact milk yield and quality (Moberg and Mench, 2000; Etim et al., 2013). In the present study, we did not evaluate physiological indicators of stress in the water buffalo cows, so we can only hypothesize that the most reactive cows were more susceptible to stress and, consequently, less efficient at redirecting their energy to milk production. This would explain the lower milk yield with lower fat content of the reactive cows (MRS 3+4).

The distance traveled by the cows did not relate to milk yield nor composition, and there was only a significant linear relation between DDT and LSCS. Such results contradict the belief that animals that travel greater distances produce less milk with lower quality because they allocate more energy to physical activities (Bewley et al., 2010; Norring et al., 2012). In a study comparing the impact of rearing water

Table 2

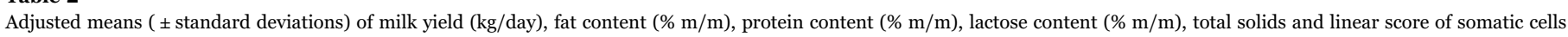
(LSCS) according to milking reactivity score (MRS).

\begin{tabular}{|c|c|c|c|c|c|c|}
\hline \multirow[t]{2}{*}{ MRS scores } & \multicolumn{6}{|c|}{ Dependent variables } \\
\hline & Milk yield & Fat content & Protein content & Lactose content & Total solids & LSCS \\
\hline 1 & $8.37 \pm 0.69^{\mathrm{a}}$ & $6.20 \pm 0.36^{\mathrm{a}, \mathrm{b}}$ & $4.23 \pm 0.10^{\mathrm{a}}$ & $4.94 \pm 0.05^{\mathrm{a}}$ & $16.31 \pm 0.39^{\mathrm{a}}$ & $4.84 \pm 0.12^{\mathrm{ab}}$ \\
\hline 2 & $7.12 \pm 0.76^{\mathrm{b}}$ & $6.56 \pm 0.41^{\mathrm{a}}$ & $4.22 \pm 0.12^{\mathrm{a}}$ & $4.88 \pm 0.05^{\mathrm{a}}$ & $16.58 \pm 0.45^{\mathrm{a}}$ & $4.65 \pm 0.13^{b}$ \\
\hline $3+4$ & $5.82 \pm 1.07^{\mathrm{b}}$ & $5.26 \pm 0.58^{\mathrm{b}}$ & $4.18 \pm 0.16^{\mathrm{a}}$ & $4.88 \pm 0.08^{\mathrm{a}}$ & $15.28 \pm 0.64^{\mathrm{a}}$ & $5.08 \pm 0.19^{\mathrm{a}}$ \\
\hline
\end{tabular}

a - b Means followed by the same letter in the same column are not statistically different $(\mathrm{P}>0.05)$, according to the Tukey-Kramer test. 
buffalo heifers in a free-range manner on a natural pasture versus a confinement system on behavior, immune functions and the efficiency of reaching puberty, Sabia et al. (2014) found that although grazing animals had lower daily weight gains and weight at puberty, the age at which puberty was reached did not differ between groups. The authors concluded that whenever an adequate nutrient supply is provided by forage, the energy deficits displayed by water buffaloes kept on pasture may not be strong enough to compromise their development. Also, these animals seem to express more 'natural behaviors' and may have relatively better immune function. For bovine cattle, Lathrop et al. (1988) characterized different breeds' land use requirements for grazing activities by assessing the effects of distance traveled and grazing time on milk production. Similarly to our findings, they observed that the patterns of land use in the pasture did not influence milk production. Moreover, Wesley et al. (2012) reported significant effects of different spatial patterns of land use on heifers' performance, as measured by growth and reproductive traits. Compared to animals that explored less, those that traveled over a larger region of a given pasture area had better weight gain and a better average body weight during the days of the study. They also tended to give birth to heavier calves and had shorter anestrus periods. These results reveal the importance of pasture exploration patterns and offer some evidence for a positive (or neutral) impact of physical activity (as opposed to a negative role, as suggested by some authors). More studies are needed to further our knowledge regarding the influence of daily distance traveled on the performance of animals, such as water buffalo cows.

The linear somatic cell score was the only milk quality indicator associated with the DDT, as it showed a slight increase of 0.14 in LSCS for every kilometer traveled. This result is difficult to explain given the lack of studies on dairy water buffaloes. It is widely known that cellular immunity can be negatively affected by stress (Griffin, 1989; Carroll and Forsberg, 2007), and that exercise can be a source of physical stress in farm animals. This topic has received special attention for athlete horses (Raidal et al., 2000; Folsom et al., 2001), for whom studies have shown that the impact of exercise on immune response is complex: brief high-intensity and prolonged exhaustive exercises were found to be related to suppressive effects, whereas moderate training produced beneficial effects on defense mechanisms (Hines et al., 1996). A possible explanation for the increase in cows' LSCS with increasing DDT in the present study could be that physical stress made animals more susceptible to subclinical mastitis. However, we do not believe that this was the case in our study, since cows moved freely over the pastures and were not forced to search for scarce resources; therefore, their walking activity would not be characterized as 'intense or exhaustive exercise'. According to Gustafson (1993), dairy cows that exercised for $0.5-3 \mathrm{~km} /$ day had better health around calving compared with tied cows, as reflected in a lower frequency of treatments for diseases and fewer cases of subclinical mastitis. Given the limited number of studies assessing the effect of distance traveled on the health and milk quality of dairy animals and the lack of convergence in the results to date, we recommend further research on this topic, particularly in water buffalo cows.

\section{Conclusions}

We conclude that milking reactivity and the daily distance traveled reflect distinct aspects of water buffalo cow temperament. Although they are not associated with each other, both of these traits can be used in an integrated way for a broader assessment of these animals' temperament. Most of the cows in our study showed consistent milking reactivity, which was associated with milk yield and quality: more reactive cows had a lower milk yield with lower fat content and higher somatic cell count. On the other hand, the daily distance traveled mostly was not related to most of the production traits, with the exception of a slight increase in somatic cell count in cows that traveled greater distances. Finally, our results suggest that water buffalo cow activity levels may play an important biological role in these animals.

\section{Conflict of interest statement}

The authors declare that there is no conflict of interest associated with this publication.

\section{Acknowledgements}

We would like to thank Mr. Rafael Borges, the owner of Gondwana farm, and his team (João and Adriano) for their assistance during data collection. We also thank Franciely de Oliveira Costa, Maria Camila Ceballos, Karen Camille Rocha Góis and Natalia Aguilar (ETCO Group, FCAV-UNESP, Jaboticabal - SP, Brazil) for their assistance with data collection. This research is part of the lead author's master's thesis in the Graduate Program in Animal Science at São Paulo State University (UNESP), Jaboticabal Campus.

\section{References}

Ali, A.K.A., Shook, G.E., 1980. An optimum transformation for somatic cell concentration in milk. J. Dairy Sci. 63, 487-490.

Anderson, D.M., Kothmann, M.M., 1980. Relationship of distance traveled with diet and weather of Hereford heifers. J. Range Manag. 33, 217-220.

Bertenshaw, C., Rowlinson, P., Edge, H., Douglas, S., Shiel, R., 2008. The effect of different degrees of 'positive' human-animal interaction during rearing on the welfare and subsequent production of commercial dairy heifers. Appl. Anim. Behav. Sci. 114, 65-75.

Bewley, J.M., Boyce, R.E., Hockin, J., Munksgaard, L., Eicher, S.D., Einstein, M.E., Schutz, M.M., 2010. Influence of milk yield, stage of lactation, and body condition on dairy cattle lying behaviour measured using an automated activity monitoring sensor. J. Dairy Res. 77, 1-6.

Bidarimath, M., Aggarwal, A., 2007. Studies on cisternal and alveolar fractions \& its composition and mammary health of Murrah buffaloes administered oxytocin. Trop. Anim. Health Prod. 39, 433-438.

Borghese, A., Mazzi, M., 2005. Buffalo population and strategies in the world. In Borghese, A. (Ed.), Buffalo Production and Research. Food and Agriculture Organization of the United Nations, Rome, Italy, 1-39.

Burrow, H.M., 1997. Measurement of temperament and their relationship with performance traits of beef cattle. Anim. Breed. Abstr. 65, 478-495.

Breuer, K., Hemsworth, P.H., Barnett, J.L., Matthews, L.R., Coleman, G.J., 2000. Behavioural response to humans and the productivity of commercial dairy cows. Appl. Anim. Behav. Sci. 66, 273-288.

Café, M., Robinson, D.L., Ferguson, D.M., Mcintyre, B.L., Geesink, G.H., Greenwood, P.L., 2011. Cattle temperament: persistence of assessments and associations with productivity, efficiency, carcass and meat quality traits. J. Anim. Sci. 89, 1452-1465.

Carroll, J.A., Forsberg, N.E., 2007. Influence of stress and nutrition on cattle immunity. Vet. Clin. N. Am.-Food A 23, 105-149.

Davidson, J.A., Beede, D.K., 2003. Exercise training of late-pregnant and nonpregnant dairy cows affects physical fitness and acid-base homeostasis. J. Dairy Sci. 92 , $548-562$.

Dodzi, M.S., Muchenje, V., 2011. Avoidance-related behavioral variables and their relationship to milk yield in pasture-based dairy cows. Appl. Anim. Behav. Sci. 133, $11-17$.

Etim, N.N., Williams, M.E., Evans, E.I., Offiong, E.E.A., 2013. Physiological and behavioural responses of farm animals to stress: Implications to animal productivity. Int. J. Adv. Agric. Res. 1, 53-61.

Folsom, R.W., Littlefield-Chabaud, M.A., French, D.D., Pourciau, S.S., Mistric, L Horohov, D.W., 2001. Exercise alters the immune response to equine influenza virus and increases susceptibility to infection. Equine Vet. J. 7, 664-669.

Ganskopp, D., 2001. Manipulating cattle distribution with salt and water in large aridland pastures: a GPS/GIS assessment. Appl. Anim. Behav. Sci. 73, 251-262.

Ganskopp, D., Bohnert, D., 2006. Do pasture-scale nutritional patterns affect cattle distribution on rangelands? Rangel. Ecol. Manag. 59, 189-196.

Gustafson, G.M., 1993. Effects of daily exercise on the health of tied dairy cows. Prevent. Vet. Med. 17, 209-223.

Griffin, J.F.T., 1989. Stress and immunity: a unifying concept. Vet. Immunol. Immunopathol. 20, 263-312.

Hedlund, L., Løvlie, H., 2015. Personality and production: nervous cows produce less milk. J. Dairy Sci. 98, 5819-5828.

Hepworth, K.W., Test, P.S., Hart, R.H., Waggoner, J.W.J.R., Smith, M.A., 1991. Grazing systems, stocking rates, and cattle behavior in Southeastern Wyoming. J. Range Manag. 44, 259-262.

Hines, M.T., Schott, H.C., II, Bayly, W.M., Leroux, A.J., 1996. Exercise and immunity: a review with emphasis on the horse. J. Vet. Intern. Med. 10, 280-289.

Lathrop, W.J., Kress, D.D., Havstad, K.M., Doornbos, D.E., Ayers, E.L., 1988. Grazing behavior of rangeland beef cows differing in milk production. Appl. Anim. Behav. Sci. $21,315-327$.

Mackay, J.R.D., Turner, S.P., Hyslop, J., Deag, J.M., Haskell, M.J., 2013. Short-term temperament tests in beef cattle relate to long-term measures of behavior recorded 
in the home pen. J. Anim. Sci. 91, 4917-4924.

Martin, P., Bateson, P., 1993. Measuring Behavior: An Introductory Guide. Cambridge University Press, Cambridge, UK.

Moberg, G.P., Mench, J.A., 2000. The Biology of Animal Stress: Basic Principles and Implications for Animal Welfare. Cabi, Cambridge, UK.

Murray, T.L., Blache, D.B., Bencini, R., 2009. The selection of dairy sheep on calm temperament before milking and its effect on management and milk production Small Rumin. R 87, 45-49.

Norring, M., Valros, A., Munksgaard, L., 2012. Milk yield affects time budget of dairy cows in tie-stalls. J. Dairy Sci. 95, 102-108.

Paranhos da Costa, M.J.R., Broom, D., 2001. Consistency of side choice in the milking parlour by Holstein \pm Friesian cows and its relationship with their reactivity and milk yield. Appl. Anim. Behav. Sci. 70, 177-186.

Pathak, N. N., 1992. Behaviour and training of river buffaloes. In: Tulloh, N.M., Holmes, J.H.G. (Eds.), Buffalo Production. Elsevier, Amsterdam, The Netherlands, 223-232.

Porcionato, M.A.F., Negrão, J.A., Paiva, F.A., Delgado, T.F.G., 2009. Respostas produtivas e comportamentais durante a ordenha de vacas holandesas em inicio de lactação. Acta Sci. Anim. Sci. 31, 447-451.

Purcell, D., Arave, C.W., Walters, J.L., 1988. Relationship of three measures of behavior to milk production. Appl. Anim. Behav. Sci. 21, 307-313.

Prasad, R.M.V., Jaya, L.P., Sreenivas, K.D., 2011. Temperament of Murrah buffaloes in different lactations and its effect on the milk yield. Indian J. Anim. Res. 45, 219-222.

Prasad, R.M.V., Laxmi, P.J., 2014. Studies on the temperament of Murrah buffaloes with various udder and teat shapes and its effect on milk yield. Buffalo Bull. 33, 170-176.

Raidal, S.L., Love, D.N., Bailey, G.D., Rose, R.J., 2000. Effect of single bouts of moderate and high intensity exercise and training on equine peripheral blood neutrophil function. Res. Vet. Sci. 2, 141-146.

Réale, D., Reader, S.M., Sol, D., Mcdougall, P.T., Dingemanse, N.J., 2007. Integrating animal temperament within ecology and evolution. Biol. Rev. Camb. Philos. Soc. 82, 291-318.

Rousing, T., Bonde, M., Badsberg, J.H., Sørensen, J.T., 2004. Stepping and kicking behavior during milking in relation to response in human-animal interaction test and clinical health in loose housed dairy cows. Livest. Sci. 88, 1-8.

Sabia, E., Napolitano, F., De Rosa, G., Terzano, G.M., Barile, V.L., Braghieri, A., Pacelli, C., 2014. Efficiency to reach age of puberty and behaviour of buffalo heifers (Bubalus bubalis) kept on pasture or in confinement. Animal 11, 1907-1916.

Telezhenko, E., Keyserlingk, M.A.G., von, Talebi, A., Weary, D.M., 2012. Effect of pen size, group size, and stocking density on activity in freestall-housed dairy cows. J. Dairy Sci. 95, 3064-3069.

Thomas, C.S., Bruckmaier, R.M., Ostensson, K., Svennersten-Sjaunja, K., 2005. Effect of different milking routines on milking-related release of the hormones oxytocin, prolactin and cortisol, and on milk yield and milking performance in Murrah buffaloes. J. Dairy Res. 72, 10-18.

Uetake, K., Morita, S., Hoshiba, S., Tanaka, T., 2002. Flight distance of dairy cows and its relationship to daily routine management procedures and productivity. Anim. Sci. J. $73,279-285$.

Waiblinger, S., Menke, C., Coleman, G., 2002. The relationship between attitudes, personal characteristics and behavior of stockpeople and subsequent behavior and production of dairy cows. Appl. Anim. Behav. Sci. 79, 195-216.

Wenzel, C., Schönreiter-Fischer, S., Unshelm, J., 2003. Studies on step-kick behaviour and stress of cows during milking in an automatic milking system. Livest. Sci. 83, 237-246.

Wesley, R.L., Cibils, A.F., Mulliniks, J.T., Pollak, E.R., Petersen, M.K., Fredricksond, E.D.L., 2012. An assessment of behavioural syndromes in rangeland-raised beef cattle. Appl. Anim. Behav. Sci. 139, 183-194. 